\title{
A Noção de Engajamento: sentidos e armadilhas para a pesquisa em comunicação
}

\section{The Notion of Engagement: meanings and pitfalls for communication research}

Rafael Grohmann

Professor do Mestrado em Comunicação da Faculdade Cásper Líbero e da Escola de Comunicação e Artes da Universidade de São Paulo (ECA-USP), São Paulo, SP, Brasil.

ORCID: 0000-0003-1063-8668

<rafael-ng@uol.com.br>

\section{Como citar este artigo (How to cite this article):}

GROHMANN, Rafael. Robert A Noção de Engajamento: sentidos e armadilhas para a pesquisa em comunicação. Revista Famecos, Porto Alegre, v. 25, n. 3, p. 1-17, setembro, outubro, novembro e dezembro de 2018: ID29387. DOI: http://dx.doi.org/10.15448/1980-3729.2018.3.29387.

\section{RESUMO}

O artigo busca problematizar os sentidos da noção de "engajamento" e seus impactos e armadilhas para a pesquisa em comunicação. De um sentido político a um significado que envolve relações com obras midiáticas e marcas, a noção se refaz. Após explorar teórica e epistemologicamente algumas obras que tratam de engajamento em estudos de comunicação (principalmente a pesquisa inglesa em comunicação e os estudos de fãs), questionamos seu uso e propomos um "desengajamento" da noção de engajamento.

\section{ABSTRACT}

The paper problematizes the meanings attached to the notion of "engagement" and its impacts and pitfalls for communication research. From a political meaning to one that relates to media products and trademarks, the notion is rebuild. After exploring theoretically and epistemologically some works concerning engagement in communication studies (mainly English research in communication and fan studies), we question its use and propose a "disengagement" of such notion.

Keywords: Engagement. Communication. Epistemology.

\section{Introdução}

As palavras e os conceitos têm historicidade não só na língua, mas nos lugares (espaços, campos) onde circulam, e se atualizam nos usos (Blikstein, 2003), às vezes ressignificando o sentido original. Nomear não é, pois, um ato gratuito, mas possui implicações epistemológicas e políticas. A discussão sobre a noção de engajamento - objetivo central deste texto - e suas implicações para a pesquisa em comunicação faz parte deste contexto.

No campo da comunicação, e especialmente nos estudos de recepção, aparecem expressões para nomear as atividades dos sujeitos nos processos comunicacionais, tais como participação, empoderamento, resistência e engajamento. Contudo, não são sinônimos e tratam de perspectivas diferentes sobre as atividades e os próprios sujeitos. 
Shirky (2011) e Jenkins, Green e Ford (2014) colocam o foco principalmente na participação, entendida como "o trabalho de públicos e não simplesmente de mercados e audiências" (Jenkins; Green; Ford, 2014, p. 240) e que causaria um "excedente cognitivo" nas pessoas (Shirky, 2011). Mas participação não é uma essência: os sujeitos participam no quê? Com o quê? Como? Há diferenças teóricas dessas perspectivas, por exemplo, em relação a de Fuchs (2014), para quem somente podemos compreender participação em seu sentido democrático, a partir dos meios de produção. Seria, em sua visão, uma ideologia ("de garotos brancos com seus brinquedos participativos", Fuchs, 2014, p. 57), com um recorte de classe.

Já a expressão "resistência", que se relaciona aos estudos pioneiros dos Estudos Culturais em Birmingham Hoggart (1973); Thompson (1987); Williams (1961) e a uma herança gramsciana, é considerada por Jenkins, Green e Ford (2014) como algo ultrapassado em relação à "participação"1. Os autores diferenciam as expressões a partir da própria sintaxe: "somos resistentes a algo: ou seja, somos organizados em oposição a um poder dominante. Participamos em algo, ou seja, a participação é organizada em e através das coletividades e conectividades sociais" (Jenkins; Green; Ford, 2014, p. 206, grifos no original). 0 que está em jogo nessas perspectivas são sentidos distintos dos jogos de poder.

A ideia de "empoderamento" (ou de "sujeitos empoderados"), por sua vez, de maneira sintética, tem como uma de suas primeiras expressões Freire e Shor (1986), aqui no original empowerment, e com os seguintes significados: “a) dar poder a, b) ativar a potencialidade criativa, c) desenvolver a potencialidade criativa do sujeito, d) dinamizar a potencialidade do sujeito" (Freire e Shor, 1986, p. 11), noção aqui relacionada ao processo educacional dialógico, mas que atualmente recobre vários discursos, principalmente empoderamento das minorias - sobretudo relativo às questões de gênero, raça e sexualidade, circulando a partir de vários enunciadores, por exemplo, movimentos sociais, Organização das Nações Unidas (ONU Mulheres - Entidade das Nações Unidas para a Igualdade de Gênero e o Empoderamento das Mulheres, 2017) e a marca Avon (campanha Empodere-se - Beleza que faz sentido, 2017), com sentidos distintos. Mazetti (2009) mostra a ressignificação da expressão, entre a emancipação dos sujeitos e a commoditização de suas experiências, analisando a "emergência dos consumidores empoderados como um momento de renegociação dos papéis entre produtores e consumidores no sistema midiático

1 Não há em Jenkins, Green e Ford (2014) a crítica direta aos teóricos de Birmingham, mas ao pretenso "cheiro de mofo" da expressão "resistência" em tempos ditos "pós-ideológicos". 
e como o surgimento da possibilidade de uma reconfiguração das relações de poder nesse cenário" (Mazetti, 2009, p. 3).

$\mathrm{O}$ que podemos pensar a partir dessas terminologias que nomeiam atividades dos sujeitos é que ninguém é totalmente empoderado, resistente ou participativo. Não existe uma essência das atividades dos sujeitos em processos comunicacionais. Do contrário, poder-se-ia levar a uma "romantização" das atividades desses sujeitos, ao realçar somente aspectos positivos de sua ação, potencialmente perdendo o foco crítico dos estudos Nightingale (1996). Todas essas nomenclaturas têm que ser compreendidas em um movimento dialético, considerando expressões e expropriações Huws (2014) dos sujeitos, entre reproduções e mudanças, observando potencialidades e limites dessas noções, em protocolos metodológicos que concebam gradientes dessas atividades. Além disso, é preciso compreender que a utilização dessas terminologias revela visões de mundo, sendo necessária uma reflexividade epistemológica.

Este breve panorama sobre essas expressões é o contexto para o foco desse artigo, que é apenas uma dessas noções que pretendem nomear as atividades dos sujeitos em processos comunicacionais: a de engajamento, com o intuito de compreender e problematizar alguns sentidos e limites (ou armadilhas) ao seu uso.

\section{Explorações iniciais sobre a noção de engajamento}

Assim como as noções anteriormente mencionadas, engajamento pode ser uma expressão para nomear as atividades dos sujeitos em processos comunicacionais. É preciso, pois, buscar alguns de seus sentidos, a começar pela definição do dicionário em português. Segundo o Michaelis (2015), engajamento ou engajar-se pode significar contrato para prestar algum serviço, luta por ideais (principalmente políticos, sociais e filosóficos), alinhamento a alguma ordem de ideias ou envolvimento ativo com questões políticas. Podemos observar a questão da luta social e política com destaque nos verbetes, embora a expressão "alinhamento" tenha um sentido ambíguo².

A expressão, em português, possui uma historicidade relacionada ao engajamento político. Em Freire e Shor (1986), por exemplo, podemos observaro uso de engajamento com relação ao processo de transformação social. Segundo os autores, "devemos estar engajados na ação política contra o racismo, contra

2 Contudo, há uma observação a ser feita: parecendo estar perdida na tradução (lost in translation), a expressão possui outras entonações em outras línguas. Por exemplo, em francês significa um compromisso. Em inglês, em algum sentido, significa envolvimento. Há semelhanças no uso em português, mas o diferencial parece ser o "acento". De qualquer forma, nosso objetivo é, de alguma forma, problematizar também a tradução direta do termo. 
o sexismo, contra o capitalismo, e contra as estruturas desumanas de produção" (Freire; Shor, 1986, p. 199). Na obra, a expressão também significa engajamento "num processo permanente de iluminação da realidade com os alunos" (Freire e Shor, 1986, p. 64), em processo de mudança social e na educação libertadora.

Com sentido semelhante, há pesquisas estrangeiras na área de comunicação como Norris (2001), Rheingold (2008) e Dalhgren (2009) que relacionam comunicação e democracia a partir de termos como "engajamento político" e "engajamento cívico". Rheingold (2008), por exemplo, trata de como as mídias participativas (como a Wikipedia, em seu estudo) podem impulsionar um engajamento cívico, principalmente por parte dos mais jovens. Na mesma direção, Dalhgren (2009) coloca engajamento como sinônimo de participação, sempre em sentido político, e como esse engajamento pode ser catalisado por representações midiáticas.

Contudo, uma "virada discursiva" ocorrida nos anos 1990 e 2000, de alguma forma, auxiliou a ressignificar a noção de "engajamento", junto com toda uma gramática (relacionada principalmente ao "mundo do trabalho'), como "colaborador", por exemplo (Boltanski e Chiapello, 2009). Como nos lembra Fairclough $(2001 ; 2016)$, as mudanças discursivas, em alguma medida, se relacionam a mudanças nas práticas sociais no sentido de "mudanças na mentalidade". Essa ressemantização reposiciona o engajamento de um lugar de "transformação social" e "luta política" para a de "alinhamento" - já presente, de alguma forma, na definição do dicionário - em relação a algum foco específico, por exemplo, alguma marca. Isto é, há um alinhamento da noção de engajamento ao "novo espírito do capitalismo" (Boltanski e Chiapello, 2009), à "nova razão do mundo" (Dardot e Laval, 2016): uma mudança de sentido que neutraliza seu significado político original. Nesse contexto, conforme Fígaro.

[...] o engajamento do saber profissional do trabalhador deu novo alento ao capital. O sistema produtivo deixou de entender a mão-deobra como objeto puramente instrumental e passou a desenvolver estratégias para incorporar o saber profissional de cada trabalhador (braçal ou intelectual) aos objetivos do aumento da lucratividade (Fígaro, 2008, p. 26).

Ao comentar o cenário da cultura participativa, Mazetti (2009) também fala em um "engajamento corporativo dos usuários de mídia". Essa mudança de sentido, de alguma forma, marca a expressão na circulação dos discursos, inclusive midiáticos (Prado, 2013), como podemos mostrar, somente a título de exemplo, as seguintes manchetes de matérias da revista Exame no ano de 2016: "Aplicativos tornam eventos mais interativos ao engajar o público em tempo 
real" (21/01/2016), "Entra ano, sai ano, e os chefes seguem sem saber engajar" (20/02/2016), “Driblando a crise: como funcionários engajados multiplicam o lucro das empresas" (18/05/2016), "Outdoor training aumenta engajamento da equipe" (7/06/2016) "Brasileiros estão entre os consumidores mais engajados do mundo" $(11 / 12 / 2016)^{3}$.

Na pesquisa em comunicação, impactam principalmente os exemplos de "engajamento de público" e "consumidores engajados". Qual a visão de sujeito que está implicada nessas expressões? Em que medida que, ao tratar desse engajamento, não se estariam atualizando teorias funcionalistas que compreendem os sujeitos mais como "alvos" das marcas e empresas midiáticas, que precisam engajar os "usuários" em seus produtos? Um exemplo está em Cerqueira e Silva (2011, p. 111): "ao mesmo tempo em que está cada vez mais difícil de ser conquistado, o indivíduo 2.0, uma vez engajado, traz benefícios crescentes para as marcas". Nesse sentido, o "indivíduo" que é o alvo a ser "conquistado" ou "engajado", permanecendo o sujeito ainda o lado oculto do receptor (Sousa, 1995). Como também afirma Alves (2016), a partir de Andrejevic (2008), "o engajamento dos fãs [...] tornou-se uma das estratégias de comunicação mais utilizadas no mercado" (Alves, 2016, p. 265).

Entre o engajamento como sinônimo de luta política e transformação social e como equivalente a alinhamento corporativo há alguns gradientes que, de alguma maneira, balizam estudos de comunicação pensados a partir do lugar da recepção. O recente dossiê da revista Media Industries sobre engajamento é um indício dessa multiplicidade de sentidos da noção na pesquisa em comunicação. As organizadoras do dossiê, Annette Hill e Jeanette Steemers (2017), afirmam que, para as indústrias midiáticas, o engajamento é visto a partir dos ratings e do ponto-de-vista de algo a ser "capturado", enquanto há outras visões que priorizam questões subjetivas, cívicas e políticas. Trata-se de uma "semântica complexa [...] como conceito que captura diferentes interesses, sentimentos e envolvimento - desde o amor, o ódio até a indiferença" (Hill; Steemers, 2017, p. 3).

Procuramos, então, mostrar um panorama de estudos - principalmente na pesquisa em comunicação anglo-saxônica ${ }^{4}$ - que se valem da noção de engajamento para pensar processos comunicacionais no sentido de posicionar teórica e epistemologicamente esses estudos, observando os sentidos de "engajamento". Em geral, fala-se de engajamento com relação à mídia ou em

3 Todas as matérias estão disponíveis na Revista Exame. Endereço conta nas referências deste artigo.

4 As pesquisas foram destacadas a partir de suas relações com a noção de engajamento. Algumas obras, por exemplo, Jorge (2014), tratam da questão de "fãs", mas em nenhum momento mencionam a expressão "engajamento". 
engajamento midiático, mas os significados dessa relação com a mídia é que diferem teórica e epistemologicamente os estudos, alguns relacionando as práticas midiáticas a outros campos sociais, e outros restritos à relação entre sujeitos e obras midiáticas. Consideramos, assim, distinções em relação ao uso da noção de engajamento entre os que a pensam a partir de uma visão mais ampla, e outros que a concebem estritamente na relação sujeito-obra midiática.

\section{Entre mídia e vida cotidiana, uma visão mais ampla de engajamento}

Em Couldry (2015) e Couldry, Livingstone e Markham (2007), há uma visão de engajamento com a mídia sempre em direção à esfera pública, no sentido de mostrar como a mídia molda, facilita ou impede a participação política. Trata-se, pois, de um vínculo entre engajamento público e participação política a partir das práticas midiáticas. Os autores buscam mostrar como esse engajamento público pode ocorrer a depender de valores em comum entre as pessoas e as notícias transmitidas. Interessa, então, conceber o engajamento se houver consequências no sentido de mudanças políticas. Esse engajamento não se daria somente do lado do sujeito-receptor, mas envolveria as práticas midiáticas como um todo. Segundo Couldry (2015, p. 613), "as instituições midiáticas - desde os primórdios dos jornais, dos filmes, do rádio e da televisão, e muito antes da internet e dos celulares - sempre estiveram muito engajadas em produzir um discurso sobre as coletividades que elas congregam". Para o autor, então, há um mito de um "nós" criado por essas instituições midiáticas, inclusive pelas mídias digitais, que nos dariam a crença de que este é olugar onde agora nos reunimos, como se fosse uma forma natural de coletividade. Isso nos evidencia que Couldry (2015) está preocupado em como esses "engajamentos" são, de alguma forma, mitos criados pelas instituições midiáticas. Podemos concluir também que a noção de engajamento, apesar de aparecer com relativa frequência em Couldry, Livingstone e Markham (2007) e Couldry (2015), não é trabalhada teórica e epistemologicamente. Seu sentido se assemelha, então, a determinados "vínculos" que, muitas vezes, são fabricados ou construídos.

Já Sonia Livingstone $(2008 ; 2013)$ está preocupada com a crescente perda de explicação de noções como "audiência", que, em sua visão, não dão conta da complexidade dos processos de comunicação, em especial, de recepção, atualmente. Para ela (Livingstone, 2013), estamos em um momento do "paradigma da participação"na audienceresearch. Apesar de ser um ponto menor no argumento da autora, é preciso ressaltar que, se a expressão "paradigma" já pode ser objeto de controvérsias teóricas, considerar a participação como um paradigma nos estudos de recepção é naturalizar determinado sentido dessa expressão relacionado a uma visão hegemônica da expressão, presente em 
Jenkins (2008), Jenkins, Green e Ford (2014) e Shirky (2011) e que desconsidera ou naturaliza os embates e disputas conceituais, como em Fuchs (2014), como se participar, por si só, já fosse um paradigma. Nesse sentido, essa expressão, por si só: a) anula a historicidade dos estudos de recepção anteriores às mídias digitais, como se apenas fosse possível "participar" a partir delas; b) apresenta uma visão midiacêntrica e a-histórica das próprias tecnologias, que são fruto do trabalho humano e dos contraditórios processos sociais (Ampuja, 2015; Vieira Pinto, 2005).

Contudo, essa visão paradigmática de participação, de sentido restrito, é, de alguma forma, repensada por Livingstone em outro momento do texto, onde diz:

a participação é concedida às pessoas pelas infraestruturas midiáticas e comunicacionais que medeiam as esferas sociais, culturais ou políticas da vida? E, por outro lado, como as pessoas se engajam com, acessam as, negociam com ou contestam as mídias enquanto exploram e inventam novas maneiras de se conectarem entre si por meio e em torno das mídias? (Livingstone, 2013, p. 6).

Isto é, a ideia de participação é repensada a partir das condições desiguais de acesso e uso das mídias. E a palavra "engajamento" aparece juntamente com "acesso", "negociação" e "contestação". Dessa forma, o engajamento se relacionaria mais a um "alinhamento". Podemos perceber também como o engajamento é uma das várias atividades dos sujeitos em relação não só à "vida midiática", para usar a expressão de Deuze (2012), mas às outras esferas da vida social.

Para Livingstone (2007), então, um estudo de recepção precisa se relacionar aos debates mais amplos, no sentido de considerar "as implicações potencialmente cívicas do engajamento das audiências com a mídia na esfera pública, o contestado equilíbrio entre concepções de audiência como criativa ou commoditizada" (Livingstone, 2007, p. 52). Então, para ela, a noção de audiência perde força justamente para explicar o engajamento das pessoas com as mídias. De forma semelhante ao que propõe Couldry (2015), a noção de engajamento importa mais no sentido de reconectar atividades supostamente privadas dos sujeitos em recepção à vida cotidiana pública. A conexão das atividades dos sujeitos em relação à mídia com as atividades de forma mais ampla. Livingstone afirma:

[...] seja como indivíduos ou coletividades, as audiências se engajam em todas as esferas da sociedade (família, política, trabalho, educação) enquanto elas são moldadas tanto por seus engajamentos nessas 
esferas quanto pelas práticas culturais, institucionais e políticoeconômicas das instituições midiáticas. Então, as audiências têm uma realidade social coletiva de significância para muitas ou mesmo todas as esferas sociais. (Livingstone, 2013, p. 5).

Podemos observar, então, como as práticas midiáticas dos sujeitos e seus engajamentos se dão em um sentido próximo ao que DuGay e outros (1997) tratam como "circuito de cultura". As atividades - que Livingstone (2013) chama de "práticas de engajamento" - dos sujeitos em relação as mídias se relacionam tanto aos outros contextos da vida quanto aos moldados pelas instituições midiáticas.

A partir disso, a autora propõe falar em "literacias" (Livingstone, 2007), considerando a relação da comunicação com a educação, compreendendo engajamento em sentido crítico, a fim de promover literacias midiáticas. Isto é, analisar os processos de engajamento dos sujeitos com a mídia em termos de literacias (e cita, inclusive, Paulo Freire). Esses processos de engajamento podem ser em relação ao letramento, a processos interpretativos e a um engajamento crítico, por exemplo.

Vemos, então, como a noção de engajamento nesse conjunto de autores - pesquisadores ingleses do departamento de Mídia e Comunicações da London School of Economics - possui uma visão que contempla as atividades dos sujeitos nas relações entre mídia e sociedade, de alguma forma se assemelhando ao que Roger Silverstone ${ }^{5}$ (2002) aborda sobre a relação entre mídia e vida cotidiana, que envolve produtores e consumidores "numa atividade mais ou menos contínua de engajamento e desengajamento" (Silverstone, 2002, p. 33). Esta visão mais ampla é compartilhada por Staiger (2005) no livro Media Reception Studies: "como nosso engajamento com a mídia proporciona uma capacidade de refletir sobre a cultura e a sociedade, e aproximações e distâncias em relação a elas? Há agenciamento em nosso consumo midiático, nossa recepção e em nossas ações? Se sim, como?" (Staiger, 2005, p. 8). Ou seja, engajamento, nesse cenário, é sinônimo de envolvimento e conexão, mas não somente com as mídias, mas com possibilidades de ações que extrapolam esta esfera, com possibilidades de perspectivas críticas. Como a própria Janet Staiger (2005) diz, essas são questões para políticas públicas. $\mathrm{O}$ mesmo não acontece com os estudos de fãs, onde também a expressão "engajamento" aparece, mas em sentido mais restrito.

5 Cabe ressaltar que Roger Silverstone foi orientador de Nick Couldry. 


\section{Os sentidos de "engajamento" em estudos de fãs}

Há diferenças da abordagem apresentada no item anterior em relação a pesquisadores mais preocupados com a cultura da participação em rede, principalmente em relação à cultura dos fãs, sendo que o engajamento, nessas pesquisas, aparece em um sentido mais restrito - de relação dos sujeitos com as obras midiáticas, no sentido de ser um fã ou mesmo um hater (ou anti-fã) que, como mostra Gray (2003), é uma forma de pensar fandom no sentido de engajamento dos sujeitos em "amar" ou "odiar" determinados produtos midiáticos.

Nas conversas entre Jenkins, Ito e Boyd (2016), fica patente que a cultura participativa não necessariamente significa resistência ao status quo ${ }^{6}$ - reafirmando a visão de Jenkins, Green e Ford (2014) sobre a predominância da expressão participação em relação à resistência. O engajamento, então, para esses autores, é pensado e medido a partir da relação com a própria "cultura participativa", como no trecho em que Boyd comenta: "os jovens são posicionados como engajados ativamente na cultura participativa só porque são jovens" (Jenkins, Ito e Boyd, 2016, p. 49) ou na fala de Ito: "a maioria das minhas pesquisas tem como foco o modo como jovens pessoas se engajam em novas tecnologias e cultura digital" (Jenkins, Ito e Boyd, 2016, p. 90).

Isto é, trata-se de uma visão mais focada da noção de engajamento ligada à conexão com produtos midiáticos e à produção de conteúdo na internet, perdendo, pois, a conexão com o sentido político e, inclusive, o que significam esses vínculos com as tecnologias em termos de hegemonia, resistência, subordinação, ideologia, cultura e poder. Jenkins, Ito e Boyd (2016) consideram que os fãs criam maneiras de se engajar profundamente e contam com a ajuda de redes sociais como Facebook e Youtube para isso, mas, para eles, a cultura participativaextrapolaocontextodessasredes, nosentidodeumspreadablemedia (Jenkins; Green; Ford, 2014). É o engajamento no "espalhamento midiático", não no "espalhamento da vida social e comunicacional", em paráfrase, relacionando ao outro conjunto de autores apresentados no item anterior. A procura por um maior engajamento nesta cultura participativa é chamada por Jenkins, Ito e Boyd (2016) de um "projeto aspiracional", mas sem ligações à vida pública.

Em estudos e teorias sobre fãs, como Bird (2011), Gray (2003), Hills (2002) e Sandvoss (2005), percebemos mais claramente esse aporte mais focado no engajamento com as obras: é o engajamento estritamente com a mídia. Gray (2003), por exemplo, compreende o engajamento em "close readings" (Gray,

6 Em Fiske (1989), que podemos considerar um clássico dos estudos culturais, ainda observamos as práticas de fãs consideradas principalmente a partir de atividades de resistência - posicionamento distinto do que já observamos em Jenkins, Ito e Boyd (2016) e Jenkins, Green e Ford (2014). 
2003, p. 69) com vistas a compreender o nível de engajamento em relação à televisão (neste caso, principalmente dos anti-fãs e não-fãs) e como essa relação serve para o entendimento das textualidades midiáticas. Isto é, o engajamento em séries, filmes, músicas, por exemplo.

Para Hills (2002), o engajamento dos fãs se refere a questões imaginativas e emocionais com significância subjetiva - ou seja, à produção de sentido dos sujeitos perante às obras com os quais ele se relaciona. Mas ele considera que a recepção midiática é somente um momento dentre o repertório de práticas dos fãs, "com cada tipo de prática relacionando-se de forma específica com relacionamentos afetivos" (Hills, 2002, p. 145).

É a partir disso que Matt Hills (2002) teoriza o culto às mídias, que, segundo o autor, é capaz de "estender um engajamento com um texto ou ícone extratextualmente" (Hills, 2002, p. 145). Como afirma Clarice Greco Alves (2016), esta abordagem fenomenológica de Hills (2002) acaba por incidir mais no contexto do que no texto. No entanto, comparado às visões de Couldry (2015) e Livingstone (2007), este contexto é mais restrito, no âmbito da relação fã-obras. Este culto é formado por comunidades com "engajamentos afetivos" em comum, como "comunidades de adoração"7. Seguindo esta visão, podemos considerar que o culto às obras midiáticas é um índice ou uma expressão do engajamento midiático dos fãs.

Este engajamento diferenciaria, pois, o fã de um telespectador comum, a partir de atividades como colecionar objetos (Miller, 2013), participar de convenções (Nunes, 2015) e mesmo atividades em redes sociais (Alves, 2016). A definição de fã, para Sandvoss (2013), é o de alguém com "engajamento regular e emocionalmente comprometido com uma determinada narrativa ou texto" (Sandvoss, 2013, p. 9), ou seja, alguém com "laço emocional" com as produções. Figueiredo e Meneses (2016), ao analisar o engajamento na série Supernatural, colocam fanfics, fansongs, fanarts e fanvids (chamadas de fanworks) como "estratégias de engajamento", tomando este engajamento em sentidos de afetos do fandom e de indicativos de melhorias das narrativas.

Então, fica patente a dimensão mais restrita de engajamento nos estudos de fãs - pensada a partir dos vínculos afetivos fã-obra e suas atividades - em relação às abordagens de Couldry (2015) e Livingstone (2007) que relacionam o engajamento também a uma questão de coletividade pública, e em esferas como a educação. Contudo, em geral, podemos notar como a noção de

7 Segundo Alves (2016, p. 261), "de acordo com a intensidade desses mecanismos de adesão que reforçam o laço entre os fãs de um programa, eles podem fazer com que o engajamento do grupo ganhe ares de culto e a produção se torne cult". 
engajamento é subteorizada nesses estudos, no sentido mesmo de reflexão e vigilância epistemológica (Bourdieu, Passeron e Chamboredon, 2007).

Uma pesquisa que propõeum protocolo metodológico para pesquisas que envolvam engajamento midiático e etnografias de audiência é a de Antonio La Pastina (2005), que considera a noção de engajamento em relação à "totalidade da experiência midiática", por exemplo, "desde a leitura sobre o show até os atos de assisti-lo, falar sobre e lembra-lo, e assim por diante" (La Pastina, 2005, p. 143), em um sentido semelhante aos estudos de fãs mencionados acima. A sua proposta identifica quatro estágios para os processos de engajamento: leitura, interpretação, apropriação e mudança. Contudo, a nosso ver, estas fases não apresentam nenhuma novidade em relação ao já pesquisado nos estudos de recepção, desde os clássicos Hall (2003) e Martín-Barbero (1995) até pesquisas brasileiras mais recentes como Fausto Neto, Fabrício e Weschenfelder (2014), John (2016) e Saggin e Bonin (2016). Isso mostra, de alguma forma, que mesmo em um texto que propõe abordar centralmente a questão do engajamento, há falta de reflexividade metodológica no sentido de pensar o avanço conceitual e teórico a partir de outras pesquisas já existentes.

Portanto, o que podemos notar nos estudos discutidos acima, nas duas últimas subseções, é uma polissemia da noção de engajamento, desde engajamento midiático com vistas a uma visão mais ampla da sociedade e da cultura até engajamento somente com algumas obras, no sentido de um fã ou um anti-fã, além do engajamento corporativo, no sentido de ajustamento ou alinhamento, invisibilizando os sujeitos em recepção. Assim, a expressão acaba por perder sua capacidade explicativa de conceito ao recobrir tantos significados sem a devida reflexividade metodológica. Apresentada do modo restrito, sem qualquer vínculo para além do campo midiático, a noção de engajamento tem o sentido político esvaziado para ser reassentada em outras bases. Metodologicamente, tratar de engajamento-desengajamento dos sujeitos (sejam eles fãs, leitores, espectadores, etc.), inclusive em termos de "níveis de engajamento" pode até servir a métricas de analistas de mídias sociais, mas pode se relevar pouco complexo ou não atento às contradições e movimentos dialéticos dos processos e relações de comunicação, algo central para estudos críticos de comunicação.

\section{Considerações Finais}

A noção de engajamento, do modo como está apresentada, pode, então, mostrar-se mais uma armadilha do que uma contribuição teórico-metodológica para a pesquisa em comunicação, apesar dos "gradientes" aqui explicitados. Possíveis sinônimos para nomear atividades dos sujeitos em processos 
comunicacionais e midiáticos não se configuram do mesmo modo. Participação não é o mesmo que resistência, indivíduo não é igual ao conceito de sujeito, por exemplo. A precisão conceitual é crucial para, de um modo geral, teoria, metodologia e epistemologia da comunicação, e de modo específico, os estudos de recepção Jacks (2014). Falar em engajamento e não trazer em seu cerne a ação política é um esvaziamento do seu sentido original e uma esterilização teórico-conceitual. Mas, de alguma forma, temos notado uma "fixação de sentidos" Orlandi (2008) da expressão ligando-a a esse significado mais restrito de envolvimento com conteúdos midiáticos e marcas, de modo que seria árdua a tarefa de "revitalização" do sentido original na circulação dos discursos.

Perguntamo-nos, então, se não haveria outras formas melhores de nomear essas atividades comunicacionais e midiáticas dos sujeitos em recepção. Podemos falar, por exemplo, em conexões, relações ou mesmo vínculos, como em Sodré (2014), o vínculo comunicacional dos sujeitos com suas ações no mundo, ou mesmo a articulação, a partir de Hall (1986; 2003) e Slack (1996).

O que defendemos é uma visão mais ampla, próxima a de Couldry (2015) e Livingstone (2007), que considere a relação dos sujeitos com as mídias, mas tendo em vista que não se trata de um campo autônomo, mas se relaciona com outros campos sociais Bourdieu (1999) sem, noentanto, desconsiderarasespecificidades das relações dos sujeitos com as obras midiáticas. Isto é, restabelecer as conexões e contradições entre as atividades comunicacionais e midiáticas dos sujeitos e processos macrossociais mais gerais. Com isso, propomos um "desengajamento" da noção de engajamento nos estudos de recepção.

\section{Referências}

ALVES, Clarice Greco. TV Cult no Brasil: memória e culto às ficções televisivas em tempos de mídias digitais. Tese (Doutorado em Ciências da Comunicação). Escola de Comunicações e Artes, Universidade de São Paulo, 2016. Orientadora: Maria Immacolata Vassallo de Lopes.

AMPUJA, Marko. A Sociedade em Rede, o Cosmopolitismo eo'Sublime Digital': reflexões sobre como a História tem sido esquecida na teoria social contemporânea.

Revista Parágrafo, São Paulo v. 1, n. 3, p. 55-67, jan/jun. 2015. Disponível em:

http://revistaseletronicas.fiamfaam.br/index.php/recicofi/article/view/295/311. Acesso em: 8 fev. 2017.

ANDREJEVIC, Mark. Watching Television Without Pity: the productivity of online fans. Television \& New Media, Londres, v. 9, n. 1 p. 24-46, fev. 2008. Disponível em: $\quad$ http://eng1131adaptations.pbworks.com/f/Andrejevic,+Marc++Watching+Television+Without+Pity.pdf. Acesso em: 8 fev. 2017 
BIRD, Elizabeth. Are we all produsers now? Convergence and media audience practices. Cultural Studies, Londres, v. 25, n. 4-5, p. 502-516, set. 2011. Disponível em: < https://www.tandfonline.com/doi/abs/10.1080/09502386.2011.600532?src=re csys\&journalCode=rcus20. Acesso em: 10 fev. 2017.

BLIKSTEIN, Izidoro. Kaspar Hauser ou a Fabricação da Realidade. São Paulo: Cultrix, 2003.

BOLTANSKI, Luc; CHIAPELLO, Ève. O Novo Espírito do Capitalismo. São Paulo: Martins Fontes, 2009.

BOURDIEU, Pierre. O Poder Simbólico. Rio de Janeiro: Bertrand Brasil, 1999.

BOURDIEU, Pierre; PASSERON, Jean-Claude; CHAMBOREDON, Jean-Claude. Ofício de Sociólogo: metodologia de pesquisa na sociologia. Petrópolis: Vozes, 2007.

CERQUEIRA, Renata; SILVA, Tarcízio. Marcas e Engajamento Digital: algumas considerações. In: GOMES, Wilson; REIS, Lucas (org.). Publicidade Digital: formatos e tendências da nova fronteira publicitária. Salvador: P\&A Editora, 2011. p. 107-122.

COULDRY, Nick. The Myth of 'Us': digital networks, political change and the production of collectivity. Information, Communication and Society, Londres, v. 18, n. 6, p. 608-626, out. 2014. Disponível em:

https://www.tandfonline.com/doi/abs/10.1080/1369118X.2014.979216. Acesso em: 20 dez. 2016.

COULDRY, Nick; LIVINGSTONE, Sonia; MARKHAM, Tim. Media Consumption and Public Engagement: beyond the presumption of attention. New York: Palgrave Macmillan, 2007.

DAHLGREN, Peter. Media and Political Engagement: citizens, communication and democracy. New York: Cambridge University Press, 2009.

DARDOT, Pierre; LAVAL, Christian. A Nova Razão do Mundo: ensaio sobre a sociedade neoliberal. São Paulo: Boitempo, 2016.

DEUZE, Mark. Media Life. Cambridge: Polity Press, 2012.

DU GAY, Paul et al. Doing Cultural Studies: the story of the Sony Walkman. London: The Open University/ Sage, 1997.

ENGAJAMENTO. In: DICIONÁRIO Michaelis. São Paulo: Editora Melhoramentos, 2015. Disponível em: http://michaelis.uol.com.br. Acesso em: 2 fev. 2017.

ESCOSTEGUY, Ana Carolina. Stuart Hall: esboço de um itinerário biointelectual. Famecos, Porto Alegre, v. 10, n. 21, p. 61-74, ago. 2003. Disponível em: 
http://revistaseletronicas.pucrs.br/ojs/index.php/revistafamecos/article/ viewFile/3214/2479. Acesso em: 19 dez. 2016.

FAIRCLOUGH, Norman. Discurso e Mudança Social. Brasília: Ed. UnB, 2001.

FAIRCLOUGH, Norman. Semiose, Mediação de Ideologia: uma visão dialética. Revista Parágrafo, São Paulo, v. 4, n. 1, 17-27, jan/jun. 2016. Disponível em: http:// revistaseletronicas.fiamfaam.br/index.php/recicofi/article/view/375/372. Acesso em: 28 jan. 2017.

FAUSTO NETO, Antonio; FABRÍCIO, Laura; WESCHENFELDER, Aline. Da boate ao memorial-tapume: quando a recepção enuncia suas formas de'trabalho de luto'. In: Encontro Anual da Associação Nacional dos Programas de Pós-Graduação em Comunicação - Compós, 2014, Belem/PA. Anais da Compós 2014. Belém, PA: Compós, 2014.

FIGARO, Roseli. Relações de Comunicação no Mundo do Trabalho. São Paulo: Annablume, 2008.

FIGUEIREDO, Carolina Dantas de; MENESES, Bruna Maria de. Fandom, Fanwork e Shipping como Estratégias de Engajamento em Supernatural. Revista GEMInIS, São Carlos, v. 7, n. 2, p. 154-170, jul/dez. 2016. Disponível em: < http://www. revistageminis.ufscar.br/index.php/geminis/article/view/273/243. Acesso em: 8 fev. 2017.

FISKE, John. Understanding Popular Culture. London: Routledge, 1989.

FREIRE, Paulo; SHOR, Ira. Medo e Ousadia: o cotidiano do professor. Rio de Janeiro: Paz e Terra, 1986.

FUCHS, Christian. Social Media: a critical introduction. London: Routledge, 2014.

GRAY, Jonathan. New Audiences, NewTextualities: anti-fans and non-fans. International Journal of Cultural Studies, Londres, v. 6, n. 1, p. 64-81, mar. 2003. Disponível em: $\quad$ http://journals.sagepub.com/doi/abs/10.1177/1367877903006001004. Acesso em: 15 jan. 2017.

HALL, Stuart. On Postmodernism and Articulation: an interview with Stuart Hall (edited by Lawrence Grossberg). Journal of Communication Inquiry, Londres, v. 10, n. 2, p. 45-60, jun. 1986. Disponível em: http://journals.sagepub.com/doi/abs/10. 1177/019685998601000204. Acesso em: 16 dez. 2016.

HALL, Stuart. Significação, representação, ideologia: Althusser e os debates pósestruturalistas. In: Da Diáspora: identidades e mediações culturais. Belo Horizonte: Ed. UFMG, 2003, p. 151-186.

HILL, Annette; STEEMERS, Jeanette. Media Industries and Engagement. Media Industries, Ann Arbor, v. 4, n. 1, p. 1-5, 2017. Disponível em: https://quod.lib. 
umich.edu/m/mij/15031809.0004.105?view=text;rgn=main. Acesso em: 24 nov. 2017.

HILLS, Matt. Fan Cultures. New York: Routledge, 2002.

HOGGART, Richard. As Utilizações da Cultura: aspectos da vida cultural da classe trabalhadora - vol. I. Lisboa: Ed. Presença, 1973.

HUWS, Ursula. Labor in the Global Digital Economy: the cybertariat comes of age. New York: Monthly Review Press, 2014.

IGUALDADE de gênero e o empoderamento das mulheres. Disponível em: < http:// www.avon.com.br/belezaquefazsentido>. Acesso em: 09 fev. 2017.

JACKS, Nilda (org.). Meios e Audiências II: a consolidação dos estudos de recepção no Brasil. Porto Alegre: Sulina, 2014.

JENKINS, Henry. Cultura da Convergência. São Paulo: Aleph, 2008.

JENKINS, Henry; GREEN, Joshua; FORD, Sam. Cultura da Conexão: criando valor e significado por meio da mídia propagável. São Paulo: Aleph, 2014.

JENKINS, Henry; ITO, Mizuko; BOYD, Danah. Participatory Culture in a Networked Era. Cambridge: Polity Press, 2016.

JOHN, Valquíria Michela. Telenovela e Mundos Possíveis na Prisão: um estudo de recepção com mulheres encarceradas. In: Encontro Anual da Associação Nacional dos Programas de Pós-Graduação em Comunicação - Compós, 2016, Goiânia/GO. Anais da Compós 2016. Goiânia, GO: Compós, 2016.

LA PASTINA, Antonio. Audience Etnographies: a media engagement approach. Global Media Approach, Heathrow, v. 4, n. 6, p. 1-18, abr. 2005. Disponível em: http:// www.globalmediajournal.com/open-access/audience-ethnographies-amedia-engagement-approach.pdf. Acesso em: 16 jan. 2017.

LIVINGSTONE, Sonia. Engaging With Media: a matter of literacy? Communication, Culture and Critique, Liverpool, v. 1, n. 1, p. 51-62, fev. 2008. Disponível em: https://onlinelibrary.wiley.com/doi/pdf/10.1111/j.1753-9137.2007.00006.x. Acesso em: 12 dez. 2016.

LIVINGSTONE, Sonia. The Participation Paradigm in Audience Research. The Communication Review, Londres, v. 16, n. 1-2, p. 21-30, mar. 2013. Disponível em: $\quad$ https://www.tandfonline.com/doi/abs/10.1080/10714421.2013.757174. Acesso em: 10 dez. 2016.

MARTÍN-BARBERO, Jesús. Dos Meios às Mediações: comunicação, cultura e hegemonia. Rio de Janeiro: Ed. UFRJ, 1995. 
MAZETTI, Henrique. Cultura Participativa, Espetáculo Interativo: do 'empoderamento' ao engajamento corporativo dos usuários de mídia. In: Congresso Brasileiro de Ciências da Comunicação - Intercom, 2009, Curitiba/PR. Anais do Intercom 2009. Curitiba, PR: Intercom, 2009.

MILLER, Daniel. Trecos, Troços e Coisas: estudos antropológicos sobre a cultura material. Rio de Janeiro: Zahar, 2013.

NIGHTINGALE, Virginia. Studying Audiences: the shock of real. London: Routledge, 1996.

NORRIS, Pippa. Digital Divide: civic engagement, information poverty and the internet worldwide. Cambrdige: Cambridge University Press, 2001.

NUNES, Monica Rebecca Ferrari. Cena Cosplay: comunicação, consumo, memória nas culturas juvenis. Porto Alegre: Sulina, 2015.

ORGANIZAÇÃO das Nações Unidas. Disponível em: <http://www.onumulheres.org. br>. Acesso em: 09 fev. 2017.

ORLANDI, Eni. Discurso e Texto: formulação e circulação dos sentidos. Campinas: Ed. Pontos Editores, 2008.

PRADO, JoséLuizAidar.Convocações Biopolíticas dos Dispositivos Comunicacionais. São Paulo: Educ, 2013.

REVISTA Exame. Disponível em: <http://exame.abril.com.br>. Acesso em: 9 fev. 2017.

RHEINGOLD, Howard. Using Participatory Media and Public Voice to Encourage Civic Engagement. In: BENNET, Lance et al. (org.). Civic Life Online: learning how digital media can engage youth. Cambridge: The MIT Press, 2008. p. 97-118.

SAGGIN, Lívia; BONIN, Jiani. Problematizações para pensar as apropriações/produções digitais de jovens. In: Encontro Anual da Associação Nacional dos Programas de Pós-Graduação em Comunicação - Compós, 2016, Goiânia/GO. Anais do XXV Encontro Anual da Compós. Goiânia: 2016.

SANDVOSS, Cornel. Fans: the mirror of consumption. Cambridge: Polity, 2005.

SANDVOSS, Cornel. Quando estrutura e agência se encontram: os fãs e o poder. Ciberlegenda, Rio de Janeiro, v. 28, n. 28, p. 08-41, jan. 2013. Disponível em: http://www.ciberlegenda.uff.br/index.php/revista/article/view/639/340. Acesso em: 30 jan. 2017.

SHIRKY, Clay. A Cultura da Participação: criatividade e generosidade no mundo conectado. Rio de Janeiro: Zahar, 2011.

SILVERSTONE, Roger. Por que estudar a mídia? São Paulo: Loyola, 2002. 
SLACK, Jennifer Daryl. The Theory and Method of Articulation in Cultural Studies. In: MORLEY, David; CHEN, Kuan-Hsing (org.). Stuart Hall: critical dialogues in cultural studies. London: Routledge, 1996. p. 112-127.

SODRÉ, Muniz. A Ciência do Comum: notas para o método comunicacional. Petrópolis: Vozes, 2014.

SOUSA, Mauro Wilton de. (org). Sujeito, o lado oculto do receptor. São Paulo: Brasiliense, 1995.

STAIGER, Janet. Media Reception Studies. New York: New York University Press, 2005.

THOMPSON, Edward Palmer. A Formação da Classe Operária Inglesa. Vol I. Rio de Janeiro: Paz e Terra, 1987.

VIEIRA PINTO, Álvaro. O Conceito de Tecnologia. Vol I. Rio de Janeiro: Contraponto, 2005.

WILLIAMS, Raymond. The Long Revolution. Harmondsworth: Penguin, 1961.

WOLTON, Dominique. Informar Não É Comunicar. Porto Alegre: Sulina, 2010.

Recebido em: 06/12/2017

Aceito em: 21/03/2018

Dados do autor:

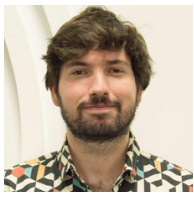

Rafael Grohmann | rafael-ng@uol.com.br

Universidade de São Paulo (ECA-USP)

Doutor e Mestre em Ciências da Comunicação pela Universidade de São Paulo (USP). Professor do Mestrado

em Comunicação da Faculdade Cásper Líbero. Professor Contratado III da Escola de Comunicação e Artes da Universidade de São Paulo (ECA-USP). Realiza estágio pós-doutoral na ECO-UFRJ, sob a supervisão do professor Muniz Sodré.

Endereço do autor:

Escola de Comunicação e Artes - Universidade de São Paulo (ECA-USP)

Av. Professor Lúcio Martins Rodrigues, 443

Cidade Universitária

05.508-020 - São Paulo, São Paulo, Brasil. 